\title{
PENGGUNAAN KLIP VIDEO DARI YOUTUBE DI DALAM ACARA TELEVISI YANG BERSIFAT KOMERSIAL DIPANDANG DARI UNDANG-UNDANG No. 28 TAHUN 2014 TENTANG HAK CIPTA
}

\author{
Retno Susilowati dan Gunawan Bagaskoro \\ Fakultas Hukum, Universitas Islam Syekh-Yusuf; Konsultan HKI \\ retnosusilowati@unis.ac.id; gbagaskoro@iploid.com
}

\section{Abstract}

The development of technology in cellular phones, cameras, digitalization, and internet create new opportunities in creating art, including cinematograpics creation and in sharing said creation to the public. Using a cellular phone, one can create and edit a film then upload saif film to video sharing platform such as Youtube, Vimeo, Metacafe, Dailymotion, etc. Problems arise when the uploaded films are being used, without the owner's consent, for a commercial activity, in this case in a commercially $T V$ show which has commercial slot in it. This article will discuss the afromentioned video usage in relation to Law No. 28 Year 2014 Regarding Copyright. The usage of uploaded videos in commercial activity infringes the copyright owner's exclusive rights and in the process of obtaining the said video disables or circumvents technological protection measures put in place by the platform.

\section{Keywords: Copyright; video sharing platform; technological protection measures}

\section{Abstrak}

Perkembangan teknologi telepon seluler, kamera, digitalisasi serta internet menimbulkan peluangpeluang baru dalam membuat ciptaan dan juga dalam hal berbagi ciptaan, termasuk di dalamnya pengumuman ciptaan. Dengan menggunakan telepon seluler, orang dapat membuat sebuah film pendek, melakukan edit, kemudian mengunggahnya ke platform berbagi video seperti Youtube, Vimeo, Metacafe, Dailymotion dan sebagainya. Masalah kemudian timbul saat video yang ada di platform, dalam hal ini Youtube, tersebut digunakan tanpa izin untuk suatu kegiatan yang bersifat komersial, dalam hal ini digunakan di acara TV yang memiliki slot iklan di dalamnya. Artikel ini membahas penggunaan video tersebut untuk sebuah acara yang bersifat komersial dipandang dari Undang-Undang No. 28 Tahun 2014 Tentang Hak Cipta. Perbuatan menggunakan video dalam acara TV komersial tersebut melanggar hak eksklusif yang dimiliki oleh pemegang hak cipta serta merusak atau membuat tidak berfungsi sarana kontrol teknologi yang dimiliki oleh Youtube tersebut.

\section{Kata kunci : Hak Cipta, Platform Berbagi Video, Sarana Kontrol Teknologi}




\section{A. Pendahuluan}

Perkembangan teknologi menyajikan kemudahan termasuk kecanggihan telepon seluler yang memiliki kemampuan makin tinggi. Saat ini merekam video berkualitas tinggi, bahkan hingga resolusi $8 \mathrm{~K}$, dapat dilakukan oleh telepon seluler. Bahkan tidak hanya merekam, melakukan edit pun bisa dilakukan oleh telepon seluler meskipun ada keterbatasan bila dibandingkan dengan proses editing yang dilakukan di komputer. Kemampuan telepon seluler ini membuat orang semakin mudah untuk membuat video dengan segala kualitas tanpa harus membeli kamera tersendiri. Selain teknologi di telepon seluler, perkembangan teknologi di bidang digital juga memegang peranan besar dalam kemudahan orang membuat film/video. Digitalisasi memudahkan sekaligus menurunkan biaya orang dalam melakukan penggandaan file digital. Teknologi digital memudahkan proses satu menjadi banyak atas file digital. ${ }^{1}$

Video yang dibuat tersebut dilindungi oleh hak cipta dan pemegang hak cipta atas video tersebut adalah pencipta atau orang yang menerima hak tersebut dari pencipta. Hak Cipta diatur di Indonesia melalui UndangUndang No. 28 Tahun 2014 Tentang Hak Cipta. Menurut Pasal 1 angka 1 Undang-Undang No. 28 Tahun 2014 Tentang Hak Cipta.

Hak Cipta adalah hak eksklusif pencipta yang timbul secara otomatis berdasarkan prinsip deklaratif setelah suatu ciptaan diwujudkan dalam bentuk nyata tanpa mengurangi pembatasan sesuai dengan ketentuan peraturan perundang-undangan.

WIPO mendefinisikan hak cipta sebagai pelindungan kepada pencipta atas karya mereka dalam bidang literatur dan artistik yang terdiri atas hak ekonomi yang memiliki jangka

\footnotetext{
${ }^{1}$ Irina Atanasova, 'Copyright Infringement in Digital Environment', Economics \& Law, 1.1 (2019), 13-22. Hlm. 13
}

waktu berlaku dan hak moral. ${ }^{2}$ Hak cipta menurut Black's Law adalah hak kepemilikan atas sebuah karya (termasuk karya sastra, musik, drama, koreografi, gambar, grafis, seni patung, karya arsitektur, film dan karya audiovisual lain, dan rekaman suara) yang diwujudkan dalam bentuk ekspresi yang nyata yang memberikan pemiliknya hak eksklusif untuk mereproduksi, mengadaptasi, mendistribusikan, mempertunjukkan, dan memamerkan karyanya. ${ }^{3}$

Salah satu kata kunci dalam definisidefinisi di atas adalah diwujudkan dalam bentuk nyata. Sebelum perkembangan komputer dan era digital, diwujudkan ini diartikan sebagai sesuatu yang bisa dirasakan secara fisik. Perkembangan dunia digital mengakibatkan ciptaan bisa diwujudkan dalam bentuk analog/ fisik atau digital saja atau keduanya. Beberapa ciptaan hanya bisa berwujud digital seperti program komputer. Sedangkan ciptaan seperti karya sastra yang dibuat di komputer lalu dicetak berwujud analog/fisik dan digital. ${ }^{4}$

Sedangkan Pencipta menurut Pasal 1 angka 2 Undang-Undang No. 28 Tahun 2014 Tentang Hak Cipta adalah seorang atau beberapa orang yang secara sendiri-sendiri atau bersama-sama menghasilkan suatu ciptaan yang bersifat khas dan pribadi. Seorang pencipta belum tentu menjadi pemegang hak cipta. Definisi pemegang hak cipta diatur dalam Pasal 1 angka 4 Undang-Undang No. 28 Tahun 2014 Tentang Hak Cipta:

Pencipta sebagai pemilik Hak Cipta, pihak yang menerima hak tersebut secara sah dari Pencipta, atau pihak lain yang menerima lebih lanjut hak dari pihak yang menerima hak tersebut secara sah.

\footnotetext{
${ }^{2}$ World Intellectual Property Organisation, 'What Is Intellectual Property?', WIPO Publication, 450(E) (2016). Hlm. 19

${ }^{3}$ Black's Law Dictionary 8th Edition, ed. by Bryan A. Garner (Eagan: Thomson Reuters, 2004). Hlm. 1020

${ }^{4}$ Irina Atanasova, 'Copyright Infringement in Digital Environment', Economics \& Law, 1.1 (2019), 13-22. Hlm. 14
} 
Menurut Pasal 4 Undang-Undang No. 28 Tahun 2014 Tentang Hak Cipta hak cipta terdiri atas hak ekonomi dan hak moral. Hak moral yang dimiliki pencipta menurut Pasal 5 Undang-Undang No. 28 Tahun 2014 Tentang Hak Cipta adalah:

a. tetap mencantumkan atau tidak mencantumkan namanya pada salinan sehubungan dengan pemakaian Ciptaannya untuk umum;

b. menggunakan nama aliasnya atau samarannya;

c. mengubah Ciptaannya sesuai dengan kepatutan dalam masyarakat;

d. mengubah judul dan anak judul Ciptaan; dan

e. mempertahankan haknya dalam hal terjadi distorsi Ciptaan, mutilasi Ciptaan, modifikasi Ciptaan, atau hal yang bersifat merugikan kehormatan diri atau reputasinya.

Hak moral tersebut tidak dapat dialihkan kepada pihak lain dan tidak memiliki masa berlaku. Bila pencipta telah meninggal dunia pelaksanaan hak moral tersebut dilakukan oleh ahli waris atau oleh sebab lain yang diperbolehkan oleh Undang-Undang. Apabila ada penolakan dari pihak yang ditunjuk tersebut, penolakan harus disampaikan secara tertulis.

Pasal 8 Undang-Undang No. 28 Tahun 2014 Tentang Hak Cipta menyatakan bahwa hak ekonomi adalah hak eksklusif pencipta atau pemegang hak cipta untuk mendapatkan manfaat ekonomi atas ciptaan. Hak ekonomi tersebut dinyatakan dalam Pasal 9 ayat (1) Undang-Undang No. 28 Tahun 2014 Tentang Hak Cipta yaitu:

a. penerbitan Ciptaan;

b. Penggandaan Ciptaan dalam segala bentuknya;

c. penerjemahan Ciptaan;

d. pengadaptasian, pengaransemenan, pentransformasian Ciptaan;

e. Pendistribusian Ciptaan atau salinannya;

f. Pertunjukan Ciptaan;

g. Pengumuman Ciptaan; h. Komunikasi Ciptaan; dan

i. penyewaan Ciptaan.

Pemegang hak cipta memiliki hak ekonomi atas ciptaan yang dimilikinya dalam jangka waktu tertentu. Secara umum jangka waktu pelindungan hak cipta adalah seumur hidup pencipta ditambah 70 tahun. Hak ekonomi tersebut dapat dialihkan kepada pihak lain berdasarkan sebab yang diatur oleh UndangUndang. Pihak lain yang melaksanakan hak ekonomi di atas harus mendapatkan izin dari pemegang hak cipta. Pelaksanaan hak ekonomi tanpa izin dari pemegang hak cipta merupakan pelanggaran atas hak ekonomi dan pemegang hak cipta memiliki wewenang untuk menegakkan hak ekonominya tersebut.

Seiring perkembangan telepon seluler, perkembangan di dunia internet yang muncul kemudian adalah platform untuk berbagi video yang dibuat oleh para pengguna platform tersebut. Platform berbagi video ini memberikan kesempatan kepada pengguna, baik pengguna pribadi maupun pembuat video profesional hingga perusahaan yang memerlukan sarana komunikasi kepada pihak lain, untuk membuat karya sinematografi yang mudah untuk didistribusikan/ditonton oleh pihak lain.

Platform berbagi video yang tersedia di internet saat ini antara lain Youtube, Vimeo, Metacafe, Dailymotion dan sebagainya. Platform berbagi video yang populer di Indonesia saat ini adalah Youtube yang tersedia secara otomatis di dalam telepon pintar yang menggunakan sistem operasi Android. Bulan Mei 2019 data Youtube menunjukkan jumlah penonton yang $\log$ in sebanyak dua miliar per bulan dan pada Oktober 2018 Youtube menguasai 21 persen lalu lintas streaming video global. ${ }^{5}$ Hingga bulan Mei 2019 lebih

\footnotetext{
${ }^{5}$ H. Tankovska, 'YouTube: Hours of Video Uploaded Every Minute 2019 | Statista', 2021 <https://www.statista.com/statistics/259477/hours-ofvideo-uploaded-to-youtube-every-minute/> [diakses 24 February 2021].
} 
dari 500 jam video yang diunggah ke Youtube setiap menit. Pertumbuhan jumlah video yang diunggah ke Youtube dari tahun 2014 hingga 2019 meningkat hingga 40\%. ${ }^{6}$

Munculnya platform berbagi video seperti Youtube memudahkan pencipta dan pemegang hak cipta dalam melakukan pengumuman dan distribusi ciptaan yang dimilikinya kepada publik/masyarakat. Pencipta atau pemegang hak cipta yang mengunggah ciptaannya ke platform harus tunduk kepada ketentuan yang berlaku pada platform tersebut. Dalam ketentuan yang ada di Youtube, ciptaan yang diunggah ke platform Youtube tetap menjadi milik pencipta atau pemegang hak cipta. Tidak terjadi pengalihan kepemilikan atas ciptaan tersebut dari pencipta atau pemegang hak cipta ke Youtube. ${ }^{7}$ Pencipta atau pemegang hak cipta memberikan lisensi kepada Youtube untuk menggunakan ciptaan tersebut dalam hal-hal yang berkaitan dengan jasa yang diberikan Youtube dan bisnis yang berkaitan dengan Youtube. ${ }^{8}$ Lisensi juga diberikan untuk sesama pengguna Youtube dalam menggunakan ciptaan milik pengguna lain sepanjang penggunaannya masih di dalam platform Youtube tersebut. Penggunaan ciptaan di luar platform Youtube tidak termasuk dalam lisensi yang dicakup dalam perjanjian dengan Youtube yang disetujui pengguna. ${ }^{9}$

Beberapa tahun belakangan ini muncul acara TV yang berisi kumpulan klip-klip video yang diambil dari Youtube dengan latar tematema tertentu seperti makanan eksotis dari negara-negara tertentu atau tempat wisata terindah dan sebagainya. Penulis amati perkembangan acara-acara tersebut awalnya hanya mencantumkan tulisan "Sumber: Youtube" atau "Diambil dari Youtube" kemudian

\footnotetext{
${ }^{6}$ loc. cit.

${ }^{7}$ Youtube, 'Terms of Service'

<https://www.youtube.com/t/terms> [diakses 24

Februari 2021].

${ }^{8}$ loc. cit.

${ }^{9}$ loc. cit.
}

berubah dengan mencantumkan tautan dari video yang digunakan di acara tersebut dan ditambah dengan nama pengunggah video atau mencantumkan "Youtube/nama pengunggah video". Kemudahan pengambilan video ini tidak terlepas dari semakin banyaknya format digital atas ciptaan pencipta. Penggunaan sebuah komputer, dan juga program komputer yang mungkin tersedia secara gratis, bisa memudahkan seseorang untuk membuat salinan atau duplikat atas sebuah ciptaan yang identik bahkan sulit untuk dibedakan dari aslinya. ${ }^{10}$

Pelanggaran atas hak cipta adalah penggunaan ciptaan yang dilindungi peraturan perundang-undangan tanpa izin yang melanggar hak eksklusif pemegang hak cipta dan/atau pencipta. ${ }^{11}$ Menurut Black's Law pelanggaran atau infringement adalah suatu perbuatan yang melanggar atau mengganggu salah satu hak eksklusif yang terdapat pada paten, hak cipta, atau pemilik merek. ${ }^{12}$

Dalam artikel ini penulis akan membahas permasalahan mengenai (1) apakah tindakan menggunakaan video Youtube untuk acara TV komersial melanggar ketentuan yang ada dalam Undang-Undang No. 28 Tahun 2014 Tentang Hak Cipta; (2) apakah tindakan menggunakan video Youtube tersebut melanggar perjanjian atau ketentuan yang dimiliki oleh Youtube.

\section{B. Metode Penelitian}

Tipe Penellitian, merupakan penelitian yuridis normatif, yang berfokus pada normanorma hukum yang berlaku, dan pengkajian norma-norma tersebut, dilakukan dengan cara meneliti data sekunder sebagai data utama,

\footnotetext{
${ }^{10}$ Roger Mwangi Gachago, 'The Effect of Technology on Institutions', Journal of Economic Issues, 15.4 (1981), 907-13. Hlm. 49

${ }^{11}$ Irina Atanasova, 'Copyright Infringement in Digital Environment', Economics \& Law, 1.1 (2019), 13-22. Hlm. 14.

12 Black's Law Dictionary 8th Edition, ed. by Bryan A. Garner (Eagan: Thomson Reuters, 2004). Hlm. 2286
} 
sedangkan data primer sebagai data penunjang. Sumber data, menggunakan sumber hukum primer, yaitu bahan-bahan hukum positif yang mengikat yang terdiri dari peraturan perundang-undangan, yaitu Undang-undang No. 28 Tahun 2014 Tentang Hak Cipta dan KUHPerdata, dan bahan hukum primer, bahanbahan hukum yang digunakan untuk memberikan penjelasan mengenai bahan hukum primer yang terdiri atas literatur-literatur, pendapatpendapat hukum dan lain-lain. Analisis data, data yang diperoleh baik bahan hukum primer/ sekunder diolah dan dianalisis secara kualitatif, dalam arti semua data yang diperoleh dianalisis secara keseluruhan, sehingga terlihat adanya gambaran yang sistematik dan faktual untuk mendapatkan pola pikir yang didasarkan pada hal-hal yang bersifat umum, kemudian ditarik kesimpulan yang bersifat khusus, untuk mendapatkan hasil kesimpulan yang dapat dipertanggungjawabkan secara ilmiah.

\section{Hasil dan Pembahasan}

\section{Apakah tindakan menggunakaan video Youtube untuk acara TV komersial melanggar ketentuan yang ada dalam Undang-Undang No. 28 Tahun 2014 Tentang Hak Cipta?}

Sharing atas video yang ada dalam Youtube dapat dilakukan oleh siapa saja dan hal tersebut dapat dilakukan tanpa harus meminta izin kepada pemegang hak cipta karena berdasarkan ketentuan yang ada dalam Youtube user atau pengguna telah memberikan lisensi kepada Youtube sesuai dengan syarat dan ketentuan yang telah disetujui oleh pengguna sepanjang distribusinya tersebut dilakukan sesuai dengan ketentuan yang ada di dalam Youtube, seperti melalui tautan langsung yang menuju ke situs Youtube atau melalui embedded player yang dimiliki oleh Youtube. Ketentuan Youtube secara jelas menyebutkan bahwa lisensi yang diberikan tersebut tidak termasuk lisensi untuk menggunakan video di luar platform Youtube. ${ }^{13}$

Penggunaan video Youtube dalam acara TV adalah tindakan menggunakan video yang ada di Youtube di luar platform Youtube itu sendiri. Yang dimaksud acara TV komersial dalam artikel ini adalah acara TV yang bukan sebuah berita dan di dalam acara tersebut terdapat slot iklan sehingga pemilik acara TV mendapatkan pemasukan dari iklan-iklan yang tayang selama acara tersebut. Acara TV yang berbentuk berita tidak kita bahas dalam permasalahan di artikel ini. Aktivitas penggunaan video dari Youtube oleh TV tersebut dapat disebut sebagai sebuah pertunjukan ciptaan dan/atau penggandaan ciptaan yang dilakukan oleh pihak lain dan menurut Pasal 9 ayat (1) Undang-Undang No. 28 Tahun 2014 Tentang Hak Cipta tindakan/perbuatan tersebut adalah hak ekonomi yang dimiliki oleh pemegang hak cipta. Pasal 2 Undang-Undang No. 28 Tahun 2014 Tentang Hak Cipta menyatakan bahwa pelaksanaan hak ekonomi tersebut oleh orang lain wajib mendapatkan izin dari pencipta atau pemegang hak cipta.

Pengecualian bisa diberikan apabila penggunaan tersebut, dengan menyebutkan atau mencantumkan sumbernya dengan lengkap, dilakukan untuk keperluan yang telah ditentukan di dalam Pasal 44 ayat (1) Undang-Undang No. 28 Tahun 2014 Tentang Hak Cipta yaitu:

a. pendidikan, penelitian, penulisan karya ilmiah, penyusunan laporan, penulisan kritik atau tinjauan

b. suatu masalah dengan tidak merugikan kepentingan yang wajar dari Pencipta atau Pemegang Hak Cipta;

c. keamanan serta penyelenggaraan pemerintahan, legislatif, dan peradilan;

d. ceramah yang hanya untuk tujuan pendidikan dan ilmu pengetahuan; atau

${ }^{13}$ Youtube, 'Terms of Service' <https://www.youtube.com/t/terms> [diakses 24 Februari 2021]. 
e. pertunjukan atau pementasan yang tidak dipungut bayaran dengan ketentuan tidak me rugikan

f. kepentingan yang wajar dari Pencipta.

Acara TV yang memiliki slot iklan di dalamnya jelas tidak termasuk dalam perbuatan atau keperluan yang dikecualikan di dalam Pasal 44 ayat (1) tersebut di atas. Dengan demikian, perbuatan menggunakan video dari Youtube tersebut di acara TV yang bersifat komersial yang ditunjukkan dengan adanya slot iklan di dalam acara tersebut, perlu mendapatkan izin dari pemegang hak cipta atas video yang digunakan tersebut karena video tersebut digunakan untuk kepentingan komersial dan video tersebut digunakan di luar platform Youtube.

Apabila izin tidak diberikan oleh pemegang hak cipta, stasiun TV yang menayangkan tersebut berarti telah melakukan pelanggaran atas hak ekonomi pemegang hak cipta. Pemegang hak cipta dapat melakukan penegakan hukum atas pelanggaran tersebut, termasuk di dalamnya mengajukan gugatan ganti rugi dan/atau pelaporan pidana atas pelanggaran tersebut. Pelanggaran tersebut dirumuskan dalam Pasal 113 ayat (2) Undang-Undang No. 28 Tahun 2014 Tentang Hak Cipta yaitu pelanggaran hak ekonomi dengan perbuatan penerjemahan ciptaan; pengadaptasian, pengaransemenan, pentransformasian Ciptaan; pertunjukan ciptaan; komunikasi ciptaan yang diancam dengan pidana penjara paling lama 4 (empat) tahun dan/atau pidana denda paling banyak lima ratus juta rupiah.

Selain itu, untuk bisa mendapatkan video tersebut, pembuat acara harus mengunduh videonya tersebut. Perbuatan ini memiliki persamaan arti dengan penggandaan atau perbuatan memperbanyak karena jumlah file tersebut bertambah satu dari jumlah asalnya serta, berbeda dengan sistem cache di dalam peramban, tidak terhapus secara otomatis oleh sistem kecuali dihapus sendiri oleh pengunduh atau orang lain. Memperbanyak adalah suatu tindakan melakukan penambahan jumlah sesuatu ciptaan, baik secara keseluruhan maupun bagian yang sangat substansial dengan menggunakan bahan yang sama ataupun tidak sama, termasuk mengalihwujudkan secara permanen atau temporer. ${ }^{14}$ Dengan demikian, perbuatan mengunduh ini bisa disamakan dengan perbuatan memperbanyak yang termasuk pelanggaran pidana berdasarkan Pasal 113 ayat (3) Undang-Undang No. 28 Tahun 2014 Tentang Hak Cipta dengan ancaman pidana penjara paling lama empat tahun dan/atau pidana denda paling banyak Rp 1.000.000.000 (satu milyar rupiah).

Gugatan ganti rugi atas pelanggaran hak cipta tersebut bisa dilakukan pemegang hak cipta melalui pengadilan niaga. Ganti rugi tersebut dapat berupa permintaan untuk menyerahkan seluruh atau sebagian pendapatan yang dihasilkan dari penyelenggaraan pertunjukan tersebut. Selain gugatan ganti rugi, pemegang hak cipta juga dapat memohon putusan sela untuk meminta penyitaan ciptaan yang dilakukan pengumuman atau menghentikan kegiatan pengumuman atau penggandaan ciptaan yang dilanggar tersebut. Atas putusan pengadilan niaga tersebut hanya dapat diajukan kasasi yang harus diajukan paling lama empat belas hari terhitung sejak putusan pengadilan niaga diucapkan dalam sidang terbuka atau diberitahukan kepada para pihak.

Perbuatan stasiun TV dalam membuat acara menggunakan video yang ada di Youtube tanpa meminta izin terlebih dahulu dari pemegang hak cipta, meskipun mencantumkan sumber video tersebut jelas merupakan sebuah pelanggaran karena perbuatan yang dilakukan tersebut bukan termasuk perbuatan yang dikecualikan oleh Undang-Undang.

\footnotetext{
${ }^{14}$ Moch Zairul Alam, 'Perbandingan Perlindungan Sarana Kontrol Teknologi Atas Ciptaan Menurut Ketentuan Hak Cipta Di Indonesia Dan Amerika Serikat', Legal Spirit, 2.1 (2018). HIm. 107
} 
Dengan demikian, apabila pihak stasiun TV ingin membuat acara komersial, izin dari pemegang hak cipta diperlukan meskipun cipta-an tersebut telah diunggah oleh pemegang hak cipta di Youtube. Pengunggahan di Youtube tunduk pada syarat dan ketentuan yang telah ditetapkan oleh pemilik platform termasuk penggunaan atas ciptaan yang ada di dalam platform Youtube tersebut. Kelalaian dalam mendapatkan izin dapat membawa konsekuensi hukum bagi stasiun TV dan juga pihak yang membuat acara tersebut.

\section{Apakah tindakan menggunakan video Youtube tersebut melanggar perjanjian atau ketentuan yang dimiliki oleh Youtube?}

Apabila penggunaan video yang ada di dalam Youtube tanpa izin dari pemegang hak cipta merupakan pelanggaran atas ketentuan dalam Undang-Undang No. 28 Tahun 2014 Tentang Hak Cipta, faktor lain yang perlu diperhatikan apakah perbuatan tersebut melanggar ketentuan yang ditetapkan oleh Youtube di dalam platformnya. Syarat dan ketentuan Youtube mengatur bahwa dalam penggunaan platform Youtube pengguna dilarang untuk, antara lain, mereproduksi, mengunduh, mendistribusikan, mentransmisikan, menyiarkan, menayangkan, menjual, melisensikan, mengubah, memodifikasi, atau menggunakan konten yang ada di dalamnya kecuali telah diizinkan secara jelas atau mendapatkan izin sebelumnya dari Youtube dan/atau pemegang hak cipta. ${ }^{15}$

Secara default, tidak ada fasilitas yang diberikan oleh Youtube untuk mengunduh video yang ada di dalamnya untuk bisa disimpan di luar platform Youtube sendiri. Fasilitas pengunduhan diberikan untuk pengguna tetapi video yang diunduh tersebut hanya bisa dilihat atau ditonton di dalam aplikasi Youtube itu sendiri, tidak bisa dilihat atau ditonton di dalam aplikasi lainnya. Ketentuan yang ditetapkan

${ }^{15}$ op. cit. oleh Youtube melarang pengguna untuk mematikan atau menghilangkan fitur keamanan yang membatasi penggandaan atau penggunaan video yang ada di Youtube.

Dengan demikian, penggunaan video You-tube di dalam acara TV tersebut melanggar ketentuan:

a. mematikan fitur keamanan yang membatasi penggandaan atau penggunaan video mengingat Youtube tidak memberikan sarana untuk mengunduh videonya selain untuk digunakan di dalam platform Youtube itu sendiri;

b. mengunduh, memodifikasi, menyiarkan video yang ada di dalam Youtube.

Menurut ketentuan tersebut hukuman atas pelanggaran yang dilakukan tersebut adalah dengan menskors atau memutuskan akses ke Youtube atau akun Google (karena Youtube merupakan salah satu jasa yang disediakan oleh Google) atau menskors atau membatalkan akses akun Google ke Youtube. Menurut pendapat penulis, penghapusan akses di sini tidak serta merta membuat Youtube tidak bisa mengajukan gugatan ganti rugi kepada pengguna yang melakukan pelanggaran. Tindakan hukum lain masih mungkin untuk dilakukan oleh Youtube atau Google kepada pihak yang melakukan pelanggaran.

Youtube membuat sarana kontrol teknologi untuk mencegah atau membatasi penggandaan atau penggunaan konten yang ada di dalam Youtube sebagaimana dinyatakan di dalam syarat dan ketentuan Youtube dan pengguna dilarang untuk mengganggu, mematikan, atau mengakali fitur yang berhubungan dengan keamanan atau fitur yang berhubungan dengan pembatasan atau pencegahan penggandaan atau penggunaan konten yang ada di dalam. Sarana kontrol teknologi menurut penjelasan Pasal 52 Undang-Undang No. 28 Tahun 2014 Tentang Hak Cipta adalah:

Setiap teknologi, perangkat, atau komponen yang dirancang untuk mencegah atau membatasi tindakan yang tidak 
diizinkan oleh Pencipta, Pemegang Hak Cipta, pemilik Hak Terkait, dan/atau yang dilarang peraturan perundangundangan.

Sarana kontrol teknologi secara luas dapat dikelompokkan menjadi dua kategori: pertama, proteksi yang digunakan untuk membatasi akses ke konten yang dilindungi untuk pengguna yang berwenang untuk akses tersebut (access function); kedua bertujuan untuk mengendalikan penggunaan konten yang dilindungi begitu pengguna memiliki akses atas ciptaan (control function). ${ }^{16}$

Pasal 52 tersebut mengatur tentang pelarangan setiap orang untuk merusak, memusnahkan, menghilangkan, atau membuat tidak berfungsi sarana kontrol teknologi yang digunakan sebagai pelindung ciptaan atau produk hak terkait serta pengaman hak cipta atau hak terkait. Secara standar, Youtube tidak memberikan fasilitas untuk mengunduh konten atau video yang ada di dalam platformnya selain untuk digunakan atau diakses di dalam aplikasi Youtube itu sendiri. Hal ini dilakukan karena lisensi yang diberikan oleh pemegang hak cipta kepada Youtube adalah lisensi untuk menggunakan ciptaan tersebut dalam kaitannya dengan jasa yang diberikan Youtube. Sehingga apabila ada penggunaan konten Youtube di luar platform Youtube tersebut, pengguna perlu mendapatkan izin dari pemegang hak cipta dan Youtube. Lisensi dari pemegang hak cipta saja dimungkinkan apabila pengguna menghubungi langsung pemegang hak cipta dan mendapatkan ciptaan tersebut langsung dari pemegang hak cipta, bukan dengan mengunduhnya dari Youtube tanpa izin.

Perusakan terhadap sarana kontrol teknologi ini diancam dengan pidana penjara paling lama dua tahun dan/atau pidana denda mak-

${ }^{16}$ Moch Zairul Alam, 'Perbandingan Perlindungan Sarana Kontrol Teknologi Atas Ciptaan Menurut Ketentuan Hak Cipta Di Indonesia Dan Amerika Serikat', Legal Spirit, 2.1 (2018). Hlm. 108-109 simal Rp 300.000.000 berdasarkan Pasal 112 Undang-Undang No. 28 Tahun 2014 Tentang Hak Cipta. Dengan demikian, terhadap tindakan pengunduhan video atau konten yang ada di Youtube ini, pelaku telah melakukan perusakan atau telah menghilangkan atau tidak membuat berfungsi sarana kontrol teknologi yang digunakan oleh Youtube untuk melindungi kepentingan pemegang hak cipta yang telah memberikan lisensi kepada Youtube dan atas perbuatan ini Youtube dapat mengambil langkah hukum, baik dengan mengajukan gugatan ganti rugi dan/atau dengan melaporkan tindak pidana berdasarkan Pasal 112 UndangUndang No. 28 Tahun 2014 Tentang Hak Cipta.

Penggunaan video untuk kepentingan acara TV komersial sesungguhnya dapat memanfaatkan penyedia stok foto dan video yang tersedia saat ini. Mereka memang bergerak di dalam penyediaan foto, musik, video untuk digunakan secara komersial dengan lisensi yang jelas dan legal sepanjang penggunaan sesuai dengan lisensi yang dibayarkan. Penyedia stok ini antara lain Getty Images, Shutterstock dan masih banyak lagi.

\section{Simpulan}

Tindakan pengambilan video dari Youtube untuk digunakan dalam acara TV komersial merupakan pelanggaran atas hak ekonomi pencipta meskipun acara TV tersebut menuliskan sumber video yang digunakan secara lengkap. Penulisan sumber lengkap untuk sebuah acara komersial bukan merupakan pengecualian yang diatur di dalam UndangUndang No. 28 Tahun 2014 Tentang Hak Cipta.

Selain melanggar hak ekonomi pencipta, tindakan mengunduh video Youtube kemudian menggunakannya di luar platform Youtube juga melanggar ketentuan penggunaan milik Youtube. Mengingat Youtube juga menggunakan sarana kontrol teknologi untuk melindungi penggunaan video atau konten yang ada di 
platformnya agar sesuai dengan lisensi yang diterima Youtube dari pemegang hak cipta, tindakan pengunduhan video atau konten Youtube ini juga merupakan tindakan yang membuat sarana kontrol teknologi tersebut menjadi tidak berfungsi atau menghilangkan atau merusak atau memusnahkan sarana kontrol teknologi. Tindakan ini merupakan pelanggaran atas ketentuan Pasal 52 UndangUndang No. 28 Tahun 2014 Tentang Hak Cipta.

Pengguna Youtube tersebar di berbagai penjuru dunia dan sebagian besar tidak memiliki kemampuan untuk mengawasi penggunaan ciptaannya yang telah mereka unggah di Youtube. Youtube menyediakan fasilitas copyright management dan Content ID untuk memonitor penyalahgunaan ciptaan yang dimiliki pemegang hak cipta. Akan tetapi kedua alat tersebut hanya berfungsi untuk memonitor di dalam platform Youtube sendiri. Pengawasan di luar platform adalah hal yang sangat sulit dilakukan. Untuk mencegah hal tersebut, sebaiknya perlu dilakukan peningkatan kesadaran di pihak-pihak yang terkait sehingga mereka mengetahui hal apa yang boleh dilakukan atau tidak terhadap ciptaan yang berada di internet.

Salah satu perubahan di Undang-Undang No. 28 Tahun 2014 Tentang Hak Cipta adalah tindak pidana yang dirumuskan dalam UndangUndang adalah delik aduan, bukan delik biasa. Ini berarti membatasi kemampuan penegak hukum dalam memberantas pelanggaran hak cipta karena harus ada aduan dari pemegang hak cipta terlebih dahulu untuk bisa dilakukan penindakan. Bila akan ada revisi UndangUndang Hak Cipta, sebaiknya pidana pelanggaran hak cipta tersebut dimasukkan sebagai delik biasa untuk tindak pidana tertentu.

\section{DAFTAR PUSTAKA}

\section{Buku}

Alam, Moch Zairul, 2018, Perbandingan Perlindungan Sarana Kontrol Teknologi Atas Ciptaan Menurut Ketentuan Hak Cipta Di Indonesia dan Amerika Serikat, Legal Spirit

Atanasova, Irina, 2019, Copyright Infringement in Digital Environment', Economics \& Law

Gachago, Roger Mwangi, 1981, The Effect of Technology on Institutions', Journal of Economic Issues

Garner, Bryan A., ed., 2004, Black's Law Dictionary 8th Edition, Eagan: Thomson Reuters

World Intellectual Property Organisation, 2016, What Is Intellectual Property?', WIPO Publication

\section{Internet}

Tankovska, H., 'YouTube: Hours of Video Uploaded Every Minute 2019 Statista', 2021 <https://www.statista.com/statistics/25 9477/hours-of-video-uploaded-toyoutube-every-minute/> [accessed 24 February 2021]

Youtube, 'Terms of Service' <https://www.youtube.com/t/terms> [accessed 24 February 2021]

\section{Peraturan Perundang-undangan}

Kitab Undang-undang Hukum Perdata

Undang-Undang No. 28 Tahun 2014 Tentang Hak Cipta 